\title{
Cross-sectional study of hepatitis B awareness among Chinese and Southeast Asian Canadians in the Vancouver-Richmond community
}

\author{
Justin Cheung MD ${ }^{1}$, Tim K Lee $\mathrm{PhD}^{2}$, Chong-Ze Teh $\mathrm{PhD}^{2}$, Caroline YM Wang MD ${ }^{3}$, \\ WC Peter Kwan MD FRCPC ${ }^{1,4,5}$, Eric M Yoshida MD MHSc FRCPC $1,4,5$
}

\begin{abstract}
J Cheung, TK Lee, C-Z Teh, CYM Wang, WCP Kwan, EM Yoshida. Cross-sectional study of hepatitis B awareness among Chinese and Southeast Asian Canadians in the Vancouver-Richmond community. Can J Gastroenterol 2005;19(4):245-249.
\end{abstract}

BACKGROUND: Hepatitis B (HBV) is endemic and a leading cause of morbidity and mortality in Asia. British Columbia has the highest proportion of Chinese and Southeast Asians among all Canadian provinces. The present study was designed to evaluate the degree of concern for and knowledge of HBV in this high-risk community.

METHODS: Unselected patrons of two large Asian commercial centres in Richmond, British Columbia were surveyed. The variables studied were population demographics, concern for HBV, level of HBV knowledge and awareness of HBV-related cirrhosis or hepatocellular carcinoma (HCC). Associations were assessed using $\chi^{2}$ testing and multiple logistic regression analysis.

RESULTS: A total of 1008 individuals participated in the survey. Fifteen incomplete surveys were excluded. Only $7.7 \%$ felt that HBV was not a concern for the community. Only $13 \%$ of respondents felt that HBV education was adequate in the community. The main sources of community health education were their doctor's office (56.3\%) and media (49.1\%). A high number stated they were "aware" of HBV (68\%) but over $60 \%$ were unaware that HBV could cause HCC or cirrhosis and only $61.3 \%$ scored a 'reasonable' level of HBV knowledge. Higher HBV knowledge was significantly associated with increasing age $(\mathrm{P}<0.001)$, higher education $(\mathrm{P}<0.001)$ and the use of media for health education $(\mathrm{P}<0.001)$. Awareness that HBV may cause $\mathrm{HCC}$ and cirrhosis was significantly associated with age $(\mathrm{P}<0.001)$, education $(\mathrm{P}=0.006)$ and birthplace $(\mathrm{P}=0.001)$.

INTERPRETATION: HBV education is necessary in this local Asian community. Programs should target younger, less educated adults and elaborate on the potential serious health consequences of HBV. Vehicles for public education should include the physicians' offices and local media

Key Words: Asian; Chinese; Hepatitis B; Public awareness; Survey
Une étude transversale de la sensibilisation à

l'hépatite B chez des Canadiens de la communauté chinoise et sud-asiatique de Vancouver-Richmond

HISTORIQUE : L'hépatite B (VHB) est endémique et constitue une cause importante de morbidité et de mortalité en Asie. De toutes les provinces canadiennes, la Colombie-Britannique (C.-B.) présente la plus forte proportion de Chinois et de Sud-Asiatiques. La présente étude a été conçue pour évaluer le degré d'inquiétude et de connaissances au sujet du VHB au sein de cette communauté très vulnérable.

MÉTHODOLOGIE : Des clients non sélectionnés de deux grands centres commerciaux asiatiques de Richmond, en C.-B., ont été sondés. Les variables étudiées étaient la démographie de la population, l'inquiétude à l'égard du VHB, le taux de connaissances du VHB, et la sensibilisation à la cirrhose ou au carcinome hépatocellulaire $(\mathrm{CHC})$ relié au VHB. Les associations ont été évaluées au moyen du test du chi carré et de l'analyse de régression logistique multiple.

RÉSULTATS : Au total, 1008 personnes ont participé au sondage. Quinze questionnaires incomplets ont été exclus. Seulement 7,7\% des répondants pensaient que le VHB n'était pas inquiétant pour la communauté, tandis que seulement $13 \%$ étaient d'avis que l'éducation sur le VHB y était suffisante. L'éducation en santé dans la communauté provenait surtout du cabinet du médecin $(56,3 \%)$ et des médias $(49,1 \%)$. Bon nombre ont déclaré « être sensibilisés » au VHB (68\%), mais plus de $60 \%$ ne savaient pas qu'il pouvait provoquer un $\mathrm{CHC}$ ou une cirrhose, et seulement $61,3 \%$ ont obtenu un taux « raisonnable » de connaissances au sujet du VHB. Des connaissances élevées au sujet du VHB s'associaient, de manière significative, à un âge plus avancé $(\mathrm{P}<0,001)$, à une éducation plus poussée $(\mathrm{P}<0,001)$ et à l'utilisation des médias pour obtenir de l'éducation en santé $(\mathrm{P}<0,001)$. La sensibilisation au fait que le $\mathrm{VHB}$ peut provoquer un $\mathrm{CHC}$ ou un cirrhose s'associait, de manière significative, à l'âge $(\mathrm{P}<0,001)$, à l'éducation $(\mathrm{P}=0,006)$ et au lieu de naissance $(\mathrm{P}=0,001)$.

INTERPRÉTATION : Il est nécessaire de prévoir une éducation sur le VHB dans cette communauté asiatique locale. Les programmes devraient cibler les adultes jeunes et moins éduqués et être axés sur l'éventualité de graves conséquences du VHB sur la santé. Les modes d'éducation publique devraient inclure les cabinets des médecins et les médias locaux.
$\mathrm{H}$ epatitis B (HBV) is a major health problem worldwide. Approximately two billion people, one-third of the world's population, have serological evidence of past or present HBV infection and 350 million people are chronically infected (1-3). Hepatocellular carcinoma (HCC) is one of the most common causes of cancer worldwide and HBV accounts for approximately
$75 \%$ of cases (4). In China, it is estimated that $13 \%$ of the population (170 million people) are chronically infected with HBV (5). HCC is the second most common cause of cancer mortality in China and HBV is the main cause of HCC and end-stage cirrhosis (5). The HBV chronic carrier rate in Hong Kong and Taiwan is approximately $12 \%$ and $15 \%$, respectively.

${ }^{1}$ Department of Medicine, University of British Columbia; ${ }^{2}$ Cancer Control Research Program, British Columbia Cancer Agency; ${ }^{3}$ Vancouver

Medical Association; ${ }^{4}$ Chinese-Canadian Medical Society-BC Chapter; ${ }^{5}$ British Columbia Hepatitis Program of the Division of

Gastroenterology, University of British Columbia $\mathfrak{E}$ British Columbia Centre for Disease Control, Vancouver, British Columbia

Correspondence: Dr Eric M Yoshida, Vancouver General Hospital, Division of Gastroenterology, 100-2647 Willow Street, Vancouver,

British Columbia V5Z 3P1. Telephone 604-875-5371, fax 604-875-5447, e-mail eyoshida@interchange.ubc.ca

Received for publication November 25, 2004. Accepted January 12, 2005 


\begin{tabular}{|c|c|}
\hline Question (correct response) & $\begin{array}{l}\text { rrect response } \\
\text { n (\%) }\end{array}$ \\
\hline 1. In my opinion, hepatitis B is preventable (True) & $786(79.2)$ \\
\hline 2. In my opinion, hepatitis B affects adults (True) & $721(72.6)$ \\
\hline $\begin{array}{l}\text { 3. In my opinion, hepatitis B is more common in } \\
\text { China and Asia versus North America (True) }\end{array}$ & $662(66.7)$ \\
\hline 4. In my opinion, small children can have hepatitis B (True) & $637(64.1)$ \\
\hline 5. A vaccine that can prevent hepatitis B exists (True) & $648(65.3)$ \\
\hline $\begin{array}{l}\text { 6. In my opinion, in most cases, hepatitis B is only a } \\
\text { temporary infection (like the flu) (False) }\end{array}$ & $608(61.2)$ \\
\hline 7. In my opinion, hepatitis B is a cause of cirrhosis (Yes) & $393(39.6)$ \\
\hline $\begin{array}{l}\text { 8. In my opinion, hepatitis B is a cause of } \\
\text { liver cancer (True) }\end{array}$ & $389(39.2)$ \\
\hline
\end{tabular}

Canada has a large immigrant population, and British Columbia (BC) has the highest proportion of visible minorities among all provinces at $21.6 \%$ (6). The majority of immigrants in BC are from Asia, and in 2001, immigrants from China and Southeast Asia accounted for 477,725 of the total BC immigrant population of $1,009,820$ people (7).

The influx of immigrants from highly endemic HBV countries results in an increase in the baseline risk in low endemic areas, such as BC. Although universal infant vaccination for HBV has been implemented since 1992 in BC and at varying times in Asia, there still remains a significant adolescent and adult population at risk for HBV. There may be a need for education and prevention programs in this high-risk population. HBV awareness among Asian immigrants from endemic regions has not been fully assessed in North America (8). The present study aims to determine the level of concern and awareness for HBV and the demographics associated with the level of HBV knowledge among the local Chinese-Asian population.

\section{METHODS}

The University of British Columbia Behavioural Research Ethics Board approved the study. Permission to conduct a survey was also obtained from the management companies of the survey locations.

\section{Population sampling}

Participants were unselected patrons from two large Asian shopping centres in Richmond, BC. Richmond is situated immediately adjacent to Burnaby and Vancouver. These cities have the highest proportion of visible minorities among Canadian cities, at 59\%, $49 \%$ and $37 \%$, respectively (9). In 2001, $43 \%$ of the Richmond population of 164,000 people was from China, East Asia and Southeast Asia (9). The participating sites, Yaohan Center and Parker Place, are commercial shopping centres that are well-recognized to be very popular with the resident Chinese and Asian community. Both of these commercial centres function as de facto community centres, providing shopping, restaurants, food and entertainment, as well as noncommercial community events. The survey was conducted over four consecutive weekend days. The first two weekend days of surveying were conducted at one centre, while the following two weekend days were conducted at the other centre. Two to three trained Asian multilingual (Cantonese, Mandarin and English) surveyors were instructed to randomly approach Asian patrons to fill out the survey. The surveyors were instructed to approach and ask patrons to fill out a questionnaire on an undisclosed medical topic. Surveyors stated that the information would be used for education programs in the community. It was also actively stated that information was confidential and did not require submitting a name or personal medical information. Once the questionnaire was completed, it was placed under the previously filled questionnaire to ensure confidentiality. A physician was present at all times to answer questions. Respondents younger than 13 years of age were excluded. Respondents were provided a complimentary information brochure and fact sheet with the correct answers to the survey because one of the objectives of the project investigators was to create an educational experience for the participants.

\section{Questionnaire}

The content of the questionnaire was reviewed and approved by the University of British Columbia Behavioural Research Ethics Board. Overall, the questions were designed to determine the respondent's HBV knowledge base, taking care to avoid asking about personal information or sensitive issues. The questionnaire comprised two categories. The first category requested background information and the second category consisted of HBV-related questions. The questions are listed in Table 1 . The written questionnaires were offered in either English or Chinese.

\section{Statistical analysis}

Both descriptive and analytic statistical analyses were performed. For bivariate analysis, a $\chi^{2}$ test or Fisher's exact test, if necessary, was used to determine associations between demographic and knowledge variables. Variables that were found to have a twotailed $\mathrm{P}<0.05$ were included in the multivariate analysis. Multivariate analysis was performed with multiple logistic regression to determine significant independent variables for predicting HBV knowledge. The ORs of the predicting variables were also estimated using the logistic regression. The alpha level of significance for the multivariate analysis was set at 0.05 for a two-tailed test (ie, $\mathrm{P}<0.05$ ). Statistical analysis was performed using SPSS for Windows, version 11.0.1 (SPSS Inc, USA).

\section{Population characteristics}

\section{RESULTS}

A total of 1008 people responded to the survey; however, 15 surveys were excluded because of incomplete survey responses (ie, only completed one page of a two-page survey). The total number of completed surveys for analysis was 993. The demographics and characteristics of the population sampled are shown in Table 2. The population sample consisted of individuals with a mean age of 38.2 years, and $86 \%$ were younger than 55 years of age. There were similar numbers of male and female respondents (44.2\% and 55.8\%, respectively). Approximately one-third (29.9\%) were not aware of their HBV status. The majority of respondents were born in Hong Kong (43.4\%), China (31.2\%) and Taiwan (9.8\%). Respondents were relatively well-educated, with $60 \%$ having some form of postsecondary education. The majority were bilingual (73.2\%) and had family physicians (91.4\%).

\section{HBV awareness, concern and knowledge}

Sixty-eight per cent of respondents reported awareness of HBV. Only $7.7 \%$ felt that HBV was not a community concern and only $13.0 \%$ felt that HBV education was adequate in the community. The main sources of health information 
were family physician's office (56.3\%), media (49.1\%), family and friends $(24.3 \%)$ and school $(12.3 \%)$. The results of the HBV knowledge questions are summarized in Table 1. A low proportion of individuals were aware that HBV could lead to chronic disease $(61.2 \%)$, cirrhosis $(39.6 \%)$ and liver cancer (39.2\%). Only 30.0\% were aware that HBV could cause both cirrhosis and cancer. The level of HBV knowledge was considered 'reasonable' if respondents correctly answered more than four of eight questions and 'very low' if they had zero to two questions correct. Survey results demonstrated that $61.3 \%$ of respondents had a reasonable level, and $18.7 \%$ had a very low level.

The $\chi^{2}$ test was used to assess the association of HBV knowledge with several variables (Table 3 ). Only three variables (age $[\mathrm{P}<0.001]$, education $[\mathrm{P}<0.001]$ and media as a source of health information $[\mathrm{P}<0.001])$ remained significant in the logistic regression model. The ORs of these variables are listed in Table 4. Compared with the reference group of 25 years of age or younger, older participants had a higher chance of acquiring reasonable level of HBV knowledge; the OR for the age group 25 to 40 years was 2.4 , for the age group 40 to 55 years was 3.3, and for the participants 55 years of age or older was 3.8 (trend test, $\mathrm{P}<0.001$ ). On the other hand, participants with secondary education $(\mathrm{OR}=0.5)$ and elementary education $(\mathrm{OR}=0.2)$ had lower odds of scoring a reasonable level of HBV knowledge when compared with their counterparts with postsecondary education (trend test, $\mathrm{P}<0.001$ ). The OR for respondents who obtained health information from media was 1.6 compared with those who did not.

The significant variables found in the bivariate analysis were used to predict the awareness of HBV liver cirrhosis and liver cancer in another multiple logistic regression model. In this model, only age $(\mathrm{P}<0.001)$, birthplace $(\mathrm{P}=0.001)$ and education $(\mathrm{P}=0.006)$ were significant. The logistic regression analysis results are shown in Table 5. The ORs for the respondents 25 to 40 years of age, 40 to 55 years of age, and over 55 years were 4.4, 5.6 and 7.1, respectively, when compared with the 25 or younger reference group (trend test, $\mathrm{P}<0.001$ ). Respondents born in North America, Vietnam and other parts of Asia had a lower OR (0.1, 0.3 and 0.5, respectively) than the respondents from Hong Kong. Also, participants with elementary education had a lower chance $(\mathrm{OR}=0.3)$ of knowing the serious consequences of HBV than did the participants with postsecondary education.

\section{DISCUSSION}

The present study demonstrated that there is both concern and desire for further HBV education among the Asian immigrant population in the Vancouver-Richmond community. Only $7.7 \%$ of those surveyed believed that HBV was not a community concern, and only $13 \%$ of those surveyed felt that HBV education was adequate in the community. Despite $68 \%$ of respondents stating that they were aware of $\mathrm{HBV}, 40 \%$ were not aware HBV could be chronic and the majority (over $60 \%$ ) was not aware of the possible severe health consequences of $\mathrm{HBV}$, including cirrhosis and liver cancer. This suggests that although many may have heard of HBV, the community is largely unaware of the serious risks of this infection. Greater knowledge of HBV was associated with increasing age and education. The population in the present study was relatively well-educated, with $60 \%$ reporting some form of postsecondary education. We speculate that $10 \%$ to $15 \%$ of participants are chronic HBV carriers and would have a greater awareness of
TABLE 2

Population characteristics $(n=993)$

\begin{tabular}{|c|c|}
\hline Characteristic & n (\%) \\
\hline \multicolumn{2}{|l|}{ Age group, years } \\
\hline$<25$ & $243(24.5)$ \\
\hline$\geq 25$ and $<40$ & $242(24.4)$ \\
\hline$\geq 40$ and $<55$ & $368(37.1)$ \\
\hline$\geq 55$ & $140(14.1)$ \\
\hline \multicolumn{2}{|l|}{ Sex } \\
\hline Male & $439(44.2)$ \\
\hline Female & $554(55.8)$ \\
\hline \multicolumn{2}{|l|}{ Birthplace } \\
\hline Hong Kong & $431(43.4)$ \\
\hline China & $310(31.2)$ \\
\hline Taiwan & $97(9.8)$ \\
\hline Other Asia & $67(6.7)$ \\
\hline North America & $57(5.7)$ \\
\hline Vietnam & $22(2.2)$ \\
\hline Other & $9(0.9)$ \\
\hline \multicolumn{2}{|l|}{ Main language at home } \\
\hline Chinese & $876(88.2)$ \\
\hline English & $81(8.2)$ \\
\hline Other & $36(3.6)$ \\
\hline \multicolumn{2}{|l|}{ Second language at home* } \\
\hline Chinese & $158(20.9)$ \\
\hline English & $569(75.4)$ \\
\hline Other & $28(3.7)$ \\
\hline \multicolumn{2}{|l|}{ Spoken language } \\
\hline English only & $56(5.6)$ \\
\hline Chinese only & $197(19.8)$ \\
\hline Other language only & $13(1.3)$ \\
\hline Bilingual & $727(73.2)$ \\
\hline \multicolumn{2}{|l|}{ Education } \\
\hline Elementary & $55(5.5)$ \\
\hline Secondary & $340(34.2)$ \\
\hline Postsecondary & $598(60.2)$ \\
\hline \multicolumn{2}{|l|}{ Family doctor } \\
\hline Have general practitioner & $908(91.4)$ \\
\hline No general practitioner & $85(8.6)$ \\
\hline \multicolumn{2}{|l|}{ Status in Canada } \\
\hline Canadian resident & $905(91.1)$ \\
\hline Visitor & $88(8.9)$ \\
\hline \multicolumn{2}{|l|}{ Working } \\
\hline Yes & $573(57.7)$ \\
\hline No & $381(38.4)$ \\
\hline Won't tell & $39(3.9)$ \\
\hline
\end{tabular}

${ }^{*}$ Data on second spoken language at home were not reported by 238 of 993 respondents (24\%)

HBV and its consequences. Therefore, the level of HBV knowledge in the at-risk subpopulation who are HBV-negative would be expected to be even lower than the numbers obtained in the present study.

There have been few studies of the Asian population with regards to assessment of HBV knowledge in North America, and our study is the largest of this kind. In Canada, the only other study performed was also conducted in the Vancouver-Richmond area, with modestly differing results. Thompson et al (8) studied 
TABLE 3

$\chi^{2}$ test results showing population characteristics $(n=993)$ associated with level of hepatitis B virus knowledge

\begin{tabular}{|c|c|c|c|}
\hline Characteristic & $\begin{array}{c}\text { Reasonable } \\
\text { knowledge (\%) }\end{array}$ & $\begin{array}{c}\text { Not } \\
\text { reasonable } \\
\text { knowledge (\%) }\end{array}$ & $\mathbf{P}$ \\
\hline \multicolumn{4}{|l|}{ Age group, years } \\
\hline$<25$ & 41.2 & 58.8 & \multirow[t]{4}{*}{$0.000^{\prime}$} \\
\hline$\geq 25$ and $<40$ & 64.0 & 36.0 & \\
\hline$\geq 40$ and $<55$ & 70.1 & 29.9 & \\
\hline$\geq 55$ & 68.6 & 31.4 & \\
\hline \multicolumn{4}{|l|}{ Sex } \\
\hline Male & 61.3 & 38.7 & \multirow[t]{2}{*}{0.975} \\
\hline Female & 61.4 & 38.6 & \\
\hline \multicolumn{4}{|l|}{ Birthplace } \\
\hline Hong Kong & 64.7 & 35.3 & \multirow[t]{7}{*}{$0.001^{*}$} \\
\hline China & 65.2 & 34.8 & \\
\hline Taiwan & 59.8 & 40.2 & \\
\hline Vietnam & 45.5 & 54.5 & \\
\hline Other Asia & 40.3 & 59.7 & \\
\hline North America & 47.4 & 52.6 & \\
\hline Other & 66.7 & 33.3 & \\
\hline \multicolumn{4}{|c|}{ Main language spoken at home } \\
\hline Chinese & 62.3 & 37.7 & \multirow[t]{3}{*}{0.178} \\
\hline English & 55.6 & 44.4 & \\
\hline Other & 50.0 & 50.0 & \\
\hline \multicolumn{4}{|c|}{ Second language spoken at home ${ }^{\dagger}$} \\
\hline Chinese & 56.3 & 43.7 & \multirow[t]{3}{*}{0.080} \\
\hline English & 65.0 & 35.0 & \\
\hline Other & 53.6 & 46.4 & \\
\hline \multicolumn{4}{|l|}{ Spoken language } \\
\hline English only & 51.8 & 48.2 & \multirow[t]{4}{*}{0.066} \\
\hline Chinese only & 56.3 & 43.7 & \\
\hline Other language only & 46.2 & 53.8 & \\
\hline Bilingual & 63.7 & 36.3 & \\
\hline \multicolumn{4}{|l|}{ Education } \\
\hline Postsecondary & 67.9 & 32.1 & \multirow[t]{3}{*}{$0.000^{*}$} \\
\hline Secondary & 53.8 & 46.2 & \\
\hline Elementary & 36.4 & 63.6 & \\
\hline \multicolumn{4}{|l|}{ Family doctor } \\
\hline Yes & 62.4 & 37.6 & \multirow[t]{2}{*}{$0.018^{*}$} \\
\hline No & 49.4 & 50.6 & \\
\hline \multicolumn{4}{|l|}{ Working } \\
\hline Yes & 64.7 & 35.3 & \multirow[t]{3}{*}{$0.029^{*}$} \\
\hline No & 56.2 & 43.8 & \\
\hline Won't tell & 61.5 & 38.5 & \\
\hline Status in Canada & & & \\
\hline Canadian resident & 62.3 & 37.7 & $0.040^{*}$ \\
\hline Visitor & 51.1 & 48.9 & \\
\hline Information source $-\mathrm{m}$ & & & \\
\hline Yes & 69.9 & 30.1 & $0.001^{*}$ \\
\hline No & 53.1 & 46.9 & \\
\hline Information source - d & & & \\
\hline Yes & 60.8 & 39.2 & 0.710 \\
\hline No & 62.0 & 38.0 & \\
\hline Information source - pl & nacist & & \\
\hline Yes & 51.2 & 48.8 & 0.175 \\
\hline No & 61.8 & 38.2 & \\
\hline Information source - fa & //friends & & \\
\hline Yes & 65.1 & 34.9 & 0.162 \\
\hline No & 60.1 & 39.9 & \\
\hline Information source - sc & & & \\
\hline Yes & 59.8 & 40.2 & 0.718 \\
\hline No & 61.5 & 38.5 & \\
\hline
\end{tabular}

${ }^{*}$ Statistically significant at $P<0.05,{ }^{\dagger} D$ ata on second spoken language at home were not reported by 238 of 993 respondents (24\%). Reasonable knowledge defined as scoring five or more correct answers out of eight questions; Not reasonable knowledge defined as scoring four or less correct answers out of eight questions
TABLE 4

Population characteristics $(n=993)$ independently predict hepatitis $B$ virus knowledge in a logistic regression model

\begin{tabular}{lcccc}
\hline & $\begin{array}{c}\text { Reasonable } \\
\text { knowledge } \\
\text { Characteristic }\end{array}$ & $\begin{array}{c}\text { Not reasonable } \\
\text { knowledge } \\
\text { (\%) }\end{array}$ & OR (95\% Cl) & P \\
\hline $\begin{array}{l}\text { Age group, years } \\
<25\end{array}$ & 41.2 & 58.8 & 1.0 & \\
$\geq 25$ and $<40$ & 64.0 & 36.0 & $2.4(1.5-3.6)$ & $0.000^{*}$ \\
$\geq 40$ and $<55$ & 70.1 & 29.9 & $3.3(2.2-5.0)$ & $0.000^{*}$ \\
$\geq 55$ & 68.6 & 31.4 & $3.8(2.3-6.2)$ & $0.000^{*}$
\end{tabular}

Education

$\begin{array}{llccc}\text { Postsecondary } & 67.9 & 32.1 & 1.0 & \\ \text { Secondary } & 71.2 & 28.8 & 0.5(0.4-0.7) & 0.000^{*} \\ \text { Elementary } & 83.9 & 16.1 & 0.2(0.1-0.4) & 0.000^{*} \\ & & & P(\text { trend })=0.000 & \end{array}$

Information source - media

$\begin{array}{lllcl}\text { No } & 75.9 & 24.1 & 1.0 & \\ \text { Yes } & 64.3 & 35.7 & 1.6(1.3-2.2) & 0.001\end{array}$

*Statistically significant at $P<0.001$. Reasonable knowledge defined as scoring five or more correct answers out of eight questions; Not reasonable knowledge defined as scoring four or less correct answers out of eight questions

TABLE 5

Population characteristics $(n=993)$ independently predict the awareness of hepatitis $B$ virus causing cirrhosis and liver cancer in a logistic regression model

\begin{tabular}{lcccc}
\hline Characteristic & Unaware (\%) & Aware (\%) & OR (95\% Cl) & P \\
\hline Age group, years & & & & \\
$<25$ & 90.9 & 9.1 & 1.0 & \\
$\geq 25$ and $<40$ & 67.8 & 32.2 & $4.4(2.5-7.8)$ & $0.000^{*}$ \\
$\geq 40$ and $<55$ & 61.4 & 38.6 & $5.6(3.3-9.5)$ & $0.000^{*}$ \\
$\geq 55$ & 60.0 & 40.0 & $7.1(3.9-12.8)$ & $0.000^{*}$ \\
& & & $P($ trend $)=0.000$ &
\end{tabular}

Birthplace

$\begin{array}{lrrcc}\text { Hong Kong } & 67.7 & 32.3 & 1.0 & \\ \text { China } & 65.5 & 35.5 & 1.0(0.7-1.4) & 0.959 \\ \text { Taiwan } & 61.9 & 38.1 & 1.8(1.1-3.0) & 0.026 \\ \text { Vietnam } & 90.9 & 9.1 & 0.3(0.1-1.2) & 0.088 \\ \text { Other Asia } & 85.1 & 14.9 & 0.5(0.2-1.0) & 0.049 \\ \text { North America } & 96.5 & 3.5 & 0.1(0.0-0.6) & 0.009 \\ \text { Other } & 88.9 & 11.1 & 0.3(0.0-2.8) & 0.312\end{array}$

Education

\begin{tabular}{llccc} 
Postsecondary & 67.9 & 32.1 & 1.0 & \\
Secondary & 71.2 & 28.8 & $0.9(0.6-1.2)$ & 0.432 \\
Elementary & 83.9 & 16.1 & $0.3(0.1-0.6)$ & 0.002 \\
& & & $P($ trend $)=0.010$ & \\
\hline
\end{tabular}

*Statistically significant at $P<0.001$

HBV knowledge level in 147 women and reported that $85 \%$ were aware of $\mathrm{HBV}$ although they also found that there was a lack of awareness of the chronicity of the disease and the sequelae of increased risk of HCC. This study differs greatly from our study in that it involved older and far fewer participants and was restricted to women. Moreover, this study, of which HBV was only one component of a larger study of 
women's cancer health issues, was restricted to participants who voluntarily agreed to allow an interview in the home, which may have led to selection bias and an overestimation of community knowledge. Because our study included both sexes, was less intrusive and more anonymous (ie, a simple written survey as opposed to a long 'face-to-face' interview), we have a greater confidence that it may be more representative of the atrisk adult Chinese-Asian community of Vancouver-Richmond and can probably be generalized to the Canadian ChineseAsian community as a whole. In terms of community awareness of HBV in the United States, there have been recent studies published of Chinese-American women (10), CambodianAmerican women (11) and Vietnamese-American immigrants (12). These studies, all of which were conducted in Seattle, Washington by the same investigators, are considerably smaller than our own but report a similar lack of awareness of HBV with regards to cancer risk - awareness of hepatoma risk was between $50 \%$ to $60 \%$. Although there are differences between the Canadian and American health care environments, the close geographic proximity of Seattle to Vancouver, and the assumption that the Chinese-Asian communities of the two cities are similar and draw from the same immigrant pool, would suggest that the level of awareness of HBV in certain subpopulations in Asia may be suboptimal.

When one considers that Asian immigrants have been shown to constitute the largest pool of chronic HBV carriers in parts of North America with low baseline endemicity (13), and that the Chinese and Southeast Asian proportion in $\mathrm{BC}$ is the highest in Canada, it is clear that there is a need to increase the level of awareness of HBV within this community. Young adults are at the highest risk for transmission and longterm sequelae of chronic HBV infection. Our study showed that the main sources of health information in the VancouverRichmond Asian community are the media and family physician's office. We suggest that a multifaceted approach

\section{REFERENCES}

1. Zuckerman AJ. More than one-third of world's population has been infected with hepatitis B virus. BMJ 1999;318:1213.

2. World Health Organization. The World Health Report 1996. Fighting Disease. Fostering Development. Executive Summary. Geneva: World Health Organization, 1996:6-7.

3. Alter MJ. Epidemiology and prevention of hepatitis B. Semin Liver Dis 2003;23:39-46.

4. Beasley RP. Hepatitis B virus. The major etiology of hepatocellular carcinoma. Cancer 1988;61:1942-56.

5. Sun Z, Ming L, Zhu X, Lu J. Prevention and control of hepatitis B in China. J Med Virol 2002;67:447-50.

6. Statistics Canada. Visible minority population, by provinces and territories (2001 Census). Ottawa: Statistics Canada, 2001. $<$ http://www.statcan.ca/english/Pgdb/demo52d.htm> (Version current at January 14, 2005).

7. Statistics Canada. Immigrant population by place of birth, by census metropolitan areas (2001 Census). Ottawa: Statistics Canada; 2001. $<$ www.statcan.ca/english/Pgdb/demo35c.htm > (Version current at January 14, 2005)

8. Thompson MJ, Taylor VM, Yasui Y, et al. Hepatitis B knowledge and practices among Chinese Canadian women in Vancouver, British Columbia. Can J Public Health 2003;94:281-6. including schools, universities, community health services, public health departments and the Chinese-Asian media may be needed to successfully increase the level of awareness of HBV. We note that one of the secondary objectives of the present survey was to create an educational experience for the survey respondents. To this end, all respondents received brochures on HBV and an information letter which contained the correct survey answers with explanations. The subjective observations of our survey team were that the questionnaire was received with enthusiasm by the community and that there was a great desire among respondents to learn about HBV. Based on our experience, we suspect that HBV public educational programs would be well received by the ChineseAsian community.

\section{CONCLUSIONS}

The present study demonstrated a need for further HBV education among the local Asian immigrant population. This suggests that although many may have heard of HBV, the community is largely ignorant of the serious risks of this infection. Although the majority reported awareness of HBV, only a minority of respondents were aware of serious end-organ consequences of HBV. Younger and less educated individuals were less knowledgeable. Prevention programs should target these individuals and focus on the serious complications of HBV. Future HBV public health programs in the VancouverRichmond area may consider using the results of the present study as baseline for assessing effectiveness.

ACKNOWLEDGEMENTS: The present study was supported by an unrestricted research grant by GlaxoSmithKline Canada Inc. The authors sincerely thank Kristine Han, Titania Chan, Margaret Lau and Cindy Yin for their participation as surveyors for this study, and the management companies for Yaohan Center and Parker Place for allowing the use of their facilities.

9. Statistics Canada. 2001 Community Profiles: Population StatisticsPage 3 for Richmond, BC. Ottawa: Statistics Canada; 2001. Available: www12.statcan.ca/english/profil01/Details/details1pop2. $\mathrm{cfm} ? \mathrm{SEARCH}=\mathrm{BEGINS} \& \mathrm{PSGC}=59 \& \mathrm{SGC}=5915015 \& \mathrm{~A}=\& \mathrm{LAN}$ $\mathrm{G}=\mathrm{E} \&$ Province $=59 \&$ PlaceName $=$ richmond $\& C S D N A M E=$ Richmo nd\&CMA $=\&$ SEARCH=BEGINS\&DataType $=1 \&$ TypeNameE $=\mathrm{Cit}$ y\%20\%2D\%20Cit\%E9\&ID=11924 (Version current at May 26, 2004).

10. Thompson MJ, Taylor VM, Jackson JC, et al. Hepatitis B knowledge and practices among Chinese American women in Seattle, Washington. J Cancer Educ 2002;17:222-6.

11. Taylor VM, Jackson JC, Chan N, Kuniyuki A, Yasui Y. Hepatitis B knowledge and practices among Cambodian American women in Seattle, Washington. J Community Health 2002;27:151-63

12. Taylor VM, Jackson JC, Pineda M, Pham P, Fischer M, Yasui Y. Hepatitis B knowedge among Vietnamese immigrants: Implications for prevention of hepatocellular carcinoma. J Cancer Educ 2000;15:51-5.

13. Kim WR, Benson JT, Therneau TM, Torgerson HA, Yawn BP, Melton LJ III. Changing epidemiology of hepatitis B in a US community. Hepatology 2004;39:811-6. 


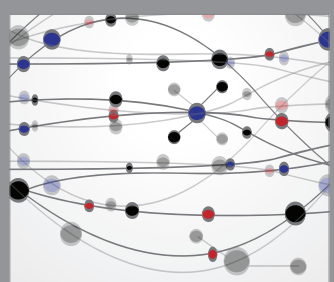

The Scientific World Journal
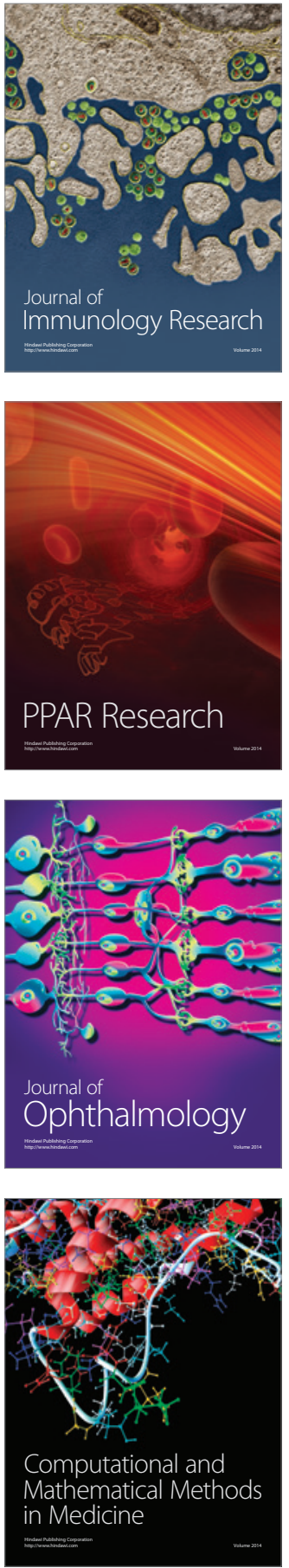

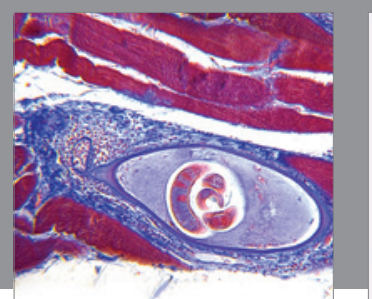

Gastroenterology Research and Practice

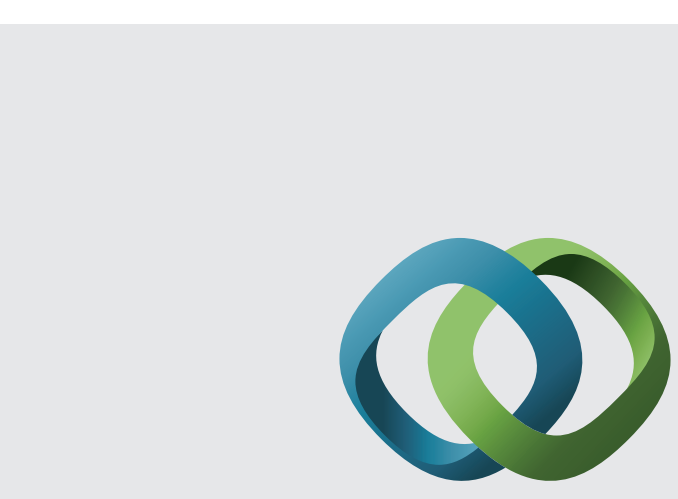

\section{Hindawi}

Submit your manuscripts at

http://www.hindawi.com
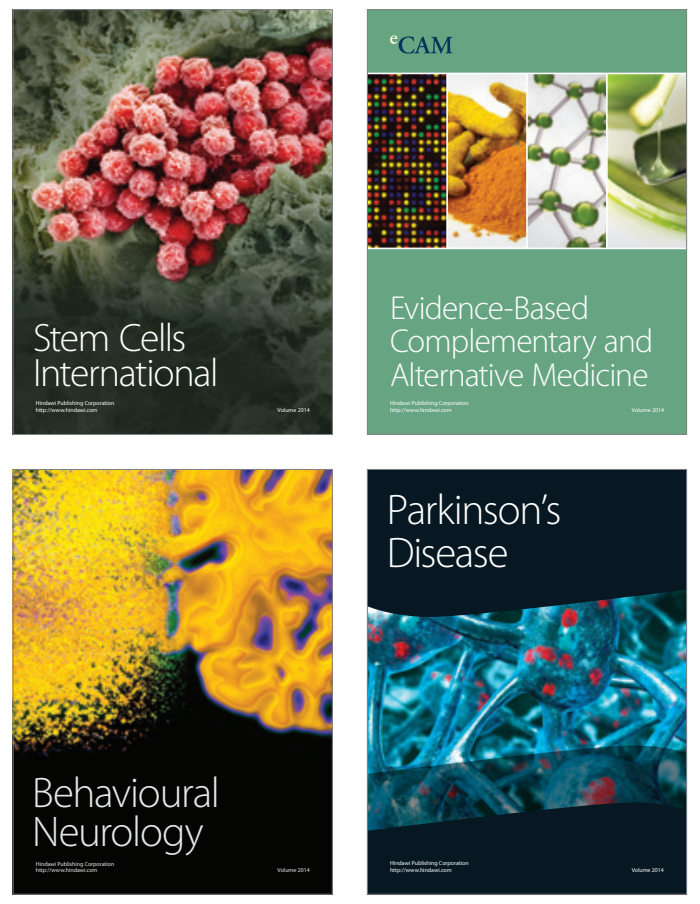
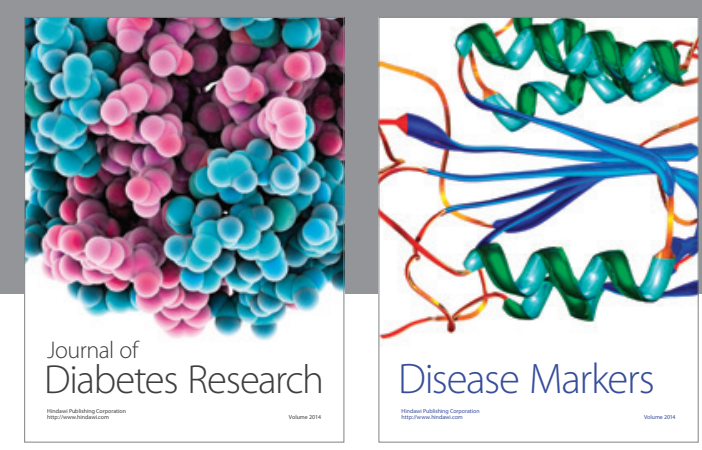

Disease Markers
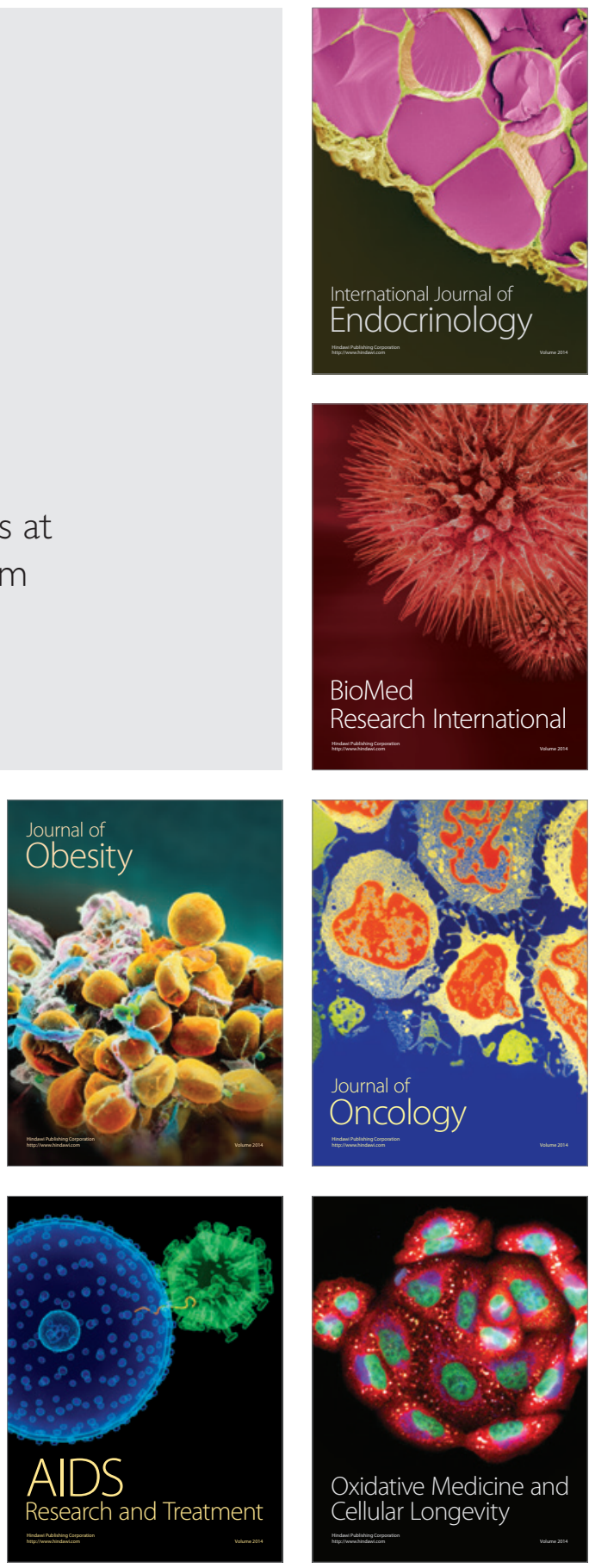